\title{
Patterns of coral community structure of subtropical reefs in the Solitary Islands Marine Reserve, Eastern Australia
}

\author{
V. J. Harriott ${ }^{1}$, S. D. A. Smith ${ }^{2}$, P. L. Harrison ${ }^{1}$ \\ ${ }^{1}$ Centre for Coastal Management, Southern Cross University, PO Box 157, Lismore, NSW 2480, Australia \\ ${ }^{2}$ Zoology Department, University of New England, Armidale, NSW 2350, Australia
}

\begin{abstract}
Although the Solitary Islands Marine Reserve lies at latitude $30^{\circ} \mathrm{S}$ on the east coast of Australia, over $700 \mathrm{~km}$ south of the Great Barrier Reef, it contains benthic communities dominated by extensive areas of scleractinian corals. A qualitative survey published in 1974 reported a total of 34 coral species in the region, and more recent records include a total of 55 coral species. Here, we present the results of the first quantitative benthic surveys for 7 sites in the Solitary Islands Marine Reserve. As a result of these surveys, an additional 35 species of scleractinian coral have been recorded from the region, bringing the total to 90 coral species, in 28 genera from 11 families. However, 21 of the 55 coral species previously recorded were not found during this study. These results indicate that a dynamic temporal pattern of species recuitment and replacement is occurring within these subtropical coral communities. Scleractinian coral cover ranged from a low of $8.5 \%$ at Muttonbird Island, the reef closest to the coastline, to $50.9 \%$ at SW Solitary Island. These values are within the range of coral cover reported for tropical fringing reefs. Multidimensional scaling (MDS) analysis indicated 4 major site groupings: the 2 sites closest to shore; the most northern offshore site, which was different from all other sites; South Solitary Island; and the other 3 island sites which showed some similarity to one another The major differences among sites were higher coral species richness and the relative importance of Acropora species on the more northern and offshore reefs, and higher abundance of large macroalgae close to the coastline. The Solitary Islands coral communities contain a unique association of tropical species near their southern latitudinal range, and subtropical scleractinian species which are rare or absent from the Great Barrier Reef region. Although coral cover is high at the Solitary Islands, these high-latitude sites are less diverse than tropical fringing reefs, with respect to both total number of coral species and the number of species per sampling unit. Furthermore, the primary substratum is formed by rock rather than limestone, so the extensive coral communities fail to form coral reefs at this latitude.
\end{abstract}

KEY WORDS: Subtropical reefs · Coral community structure

\section{INTRODUCTION}

Coral reefs are typically associated with warm shallow seas, and the geographic limits of coral reef formation generally fall within the band delineated by the northern and southern tropics (Stoddart 1969, Rosen 1988). However, in some regions, extensive coral communities may occur at higher latitudes (Veron 1974 , Veron et al. 1974, Veron \& Done 1979). These highlatitude coral communities have been little studied, compared with their tropical counterparts. A feature of high-latitude coral communities is that, despite high coral cover, they fail to form significant limestone reef structures (Veron \& Done 1979). Therefore, studies of these communities are important because they provide insights into factors controlling coral reef formation.

Before the 1970s, very few coral species had been recorded on the East Australian coastline south of Moreton Bay, Queensland (Fig. 1). Dakin (1952) reported only 1 coral species along the coast of New South Wales (NSW), and Wells (1955) reported 8 coral genera from the same region. Wells (1955) predicted that the number of coral genera should decline from 25 on the southern Great Barrier Reef to 12 in Moreton Bay and to 2 by the latitude of Sydney. 


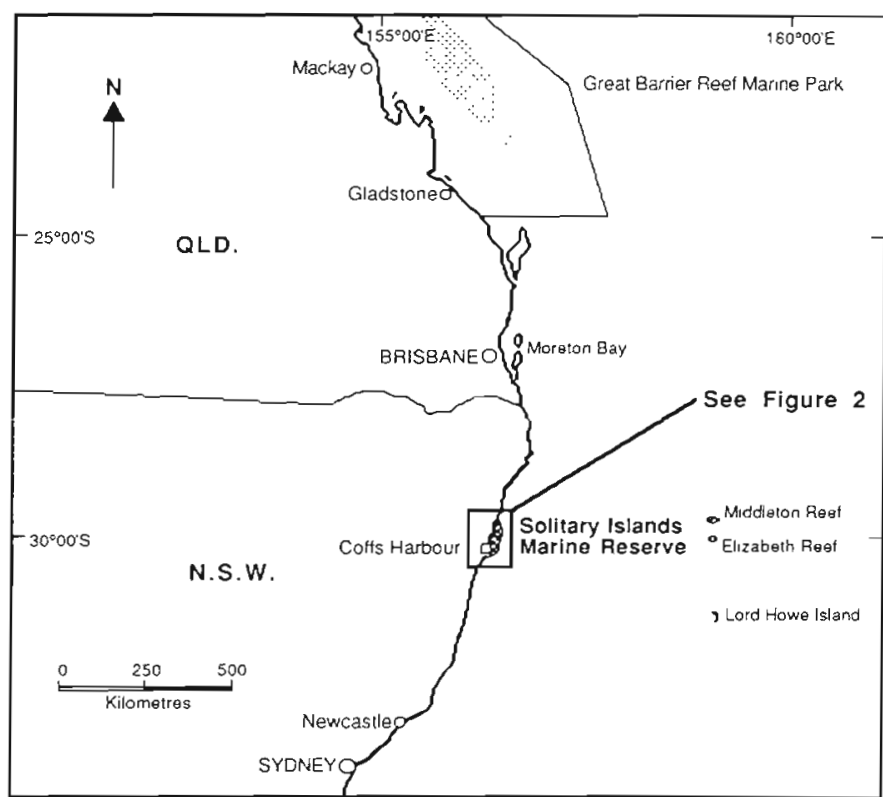

Fig. 1. Eastern Australia showing the location of the Solitary Islands Marine Reserve sary to form the basis for further ecological work and management of the Solitary Islands Marine Reserve

\section{METHODS}

Benthic community structure was examined at 7 sites within the Solitary Islands Marine Reserve, at varying distances from the mainland, and covering a latitudinal distance of approximately $45 \mathrm{~km}$ (Fig. 2). The sites at Muttonbird Isiand and Woolgoolga Reef both lie in semi-protected areas on the northern side of headlands, and less than a few hundred metres from the shoreline. The other islands lie between 2 and $11 \mathrm{~km}$ offshore (Fig. 2)

As limited field time was available for the study, and the primary aim was to examine patterns in coral species richness and cover, a stratified sampling design was used. Preliminary snorkel and scuba surveys were used to establish the areas at each site with the best-developed coral communities, and the quantitative studies were done in
There were no additional records of corals until a pioneering study of the coral communities of the Solitary Islands in northern NSW by Veron et al. (1974; Fig. 1). They recorded 34 scleractinian species in 18 genera, compared with the predicted number of fewer than 10 genera, and $100 \%$ coral cover in some localised areas. They concluded that the coral communities were similar on 4 of the 5 islands in the group, with the exception of North Solitary Island, which is further offshore and had species which were not present at the other more inshore islands. Recently Smith \& Simpson (1991) have updated the records for corals from the major headlands and associated reefs within the Solitary Islands Marine Reserve, taking the nearshore species count to 15 . However, there have been no additional published studies of coral communities in the main island group.

A reinvestigation of the coral communities of the Solitary Islands is timely for a number of reasons. Firstly, the Veron et al. (1974) surveys were not quantitative, and included coral cover estimates for only 1 island. Secondly, it is appropriate to examine whether there have been major changes in the coral community after an interval of almost $20 \mathrm{yr}$ since the original surveys. Finally, advances in Australian coral taxonomy in the past 20 yr have resulted in changes to many of the species records in Veron et al. (1974), and some additional species have subsequently been collected from the Solitary Islands (Veron 1993). An updated coral species list for this region, and quantitative information on the structure of the benthic communities, are neces-

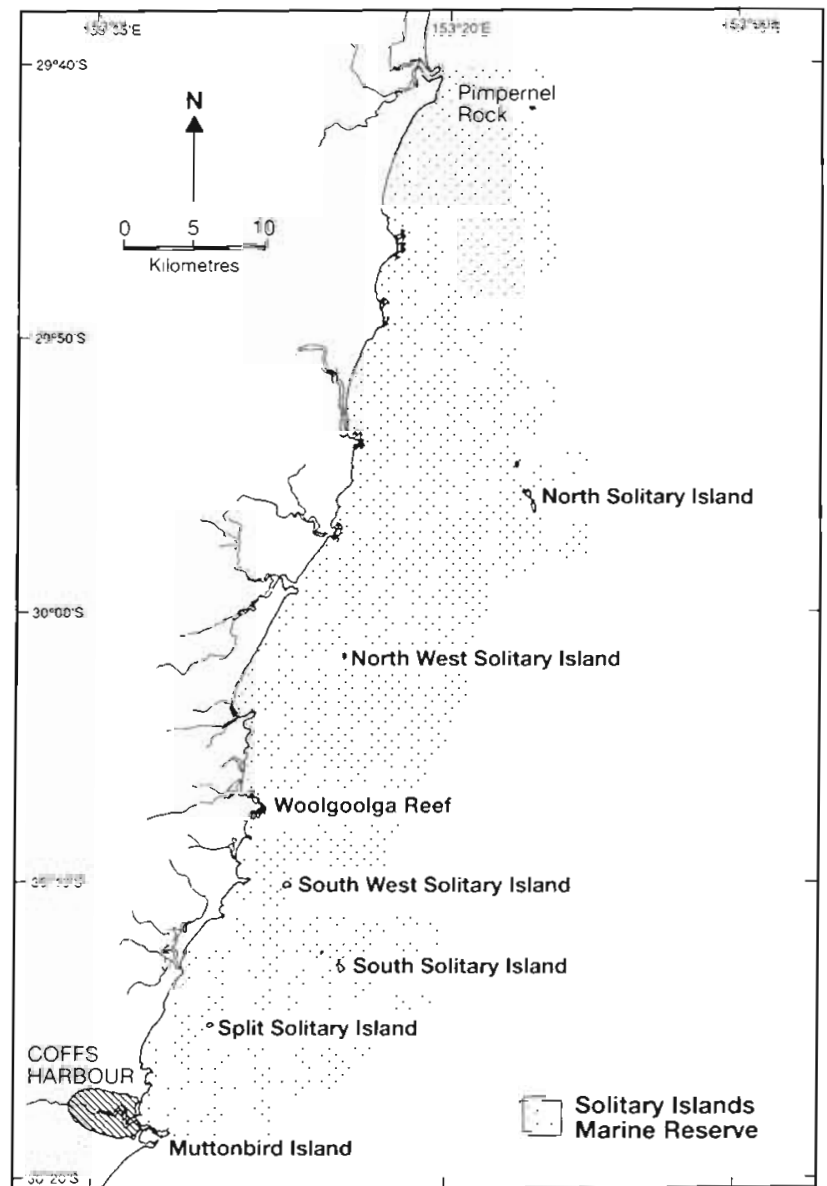

Fig. 2. Study locations within the Solitary Islands Marine Reserve 
these areas. For this reason, the results presented here are for areas likely to have maximum coral cover at each site. The depth of the zone of maximum coral cover varied at each site, but all surveys were done at depths between 5 and $9 \mathrm{~m}$. For each of the island sites, the zone of highest coral cover was on the northern or northwestern side of the island, possibly because of the protection afforded from the prevailing southerly or southeasterly wind and wave patterns.

Benthic community cover was quantified using line transects, with 4 transects of $20 \mathrm{~m}$ per site. Once the general area was selected, the 4 transects were established haphazardly within the area, and surveyed using a fibreglass tape measure. Cover was recorded by noting the length of the transect interval under the tape for each coral colony, other taxonomic groups, or substratum type. The results for each transect were collated as number of colonies, mean interval under the tape and cover for each taxonomic group or substratum type. At each site, the number of coral species recorded became asymptotic after 2 to 4 transects, indicating that the selected sampling unit of four $20 \mathrm{~m}$ line transects was appropriate for these sites. The sites at Woolgoolga Reef, SW Solitary, NW Solitary and North Solitary islands were surveyed during February 1992, while sites at Muttonbird, Split Solitary and South Solitary Islands were surveyed in November 1992.

At the 2 nearshore sites (Woolgoolga Reef and Muttonbird Island), sublittoral rocky outcrops are dominated by a mixed biotic community (Smith 1988, Smith \& Simpson 1991), each component of which is frequently numerous and small (e.g. patches of calcareous and turfing algae, ascidians and anemones). The evaluation of each of these units separately would have resulted in a considerable increase in sampling effort, so they were pooled under the classification of 'mixed algal/invertebrate community'.

At the same time as the line transects were done, 2 divers scanned the surrounding area and compiled a list of scleractinian coral species present. Species which were not common in the area, or which were difficult to identify in the field, were photographed and a small sample removed with a hammer and chisel for taxonomic identification. These coral samples were returned to the laboratory where they were bleached in a concentrated chlorine solution and then identified using the taxonomic descriptions in Veron \& Pichon (1976, 1980, 1982), Veron et al. (1977), Veron \& Wallace (1984) and Veron (1986). Specimens of Acropora were sent to the Museum of Tropical Queensland, Townsville, Australia, where they were identified by Carden Wallace and Jacqueline Wolstenholme. Representative specimens of the Acropora colonies have been retained in the reference collection of the museum. Additional coral species records from Smith \& Simpson (1991) and subsequent surveys at the study sites during 1992 and 1993 have also been included in the species lists for each site (Table 1).

Patterns of benthic cover in the line transects were examined for differences among sites using nonmetric multidimensional scaling (MDS) ordination (Field et al. 1982). Essentially, this method uses measures of similarity or dissimilarity between pairs of samples as a starting point to graphically portray the relationships in a 2-dimensional plot. Replicates with similar biological composition tend to group together and are spatially removed from dissimilar groups.

As some species/habitat classifications differed between the nearshore sites and the islands, selected habitat types were pooled to make the data equivalent. Values for barnacles, ascidians and different types of algae (turfing, macro- and calcareous) were aggregated into 1 habitat group (equivalent to the nearshore mixed algal/invertebrate community).

Raw cover data were double square-root transformed and similarities between each pair of samples were calculated using the Bray-Curtis measure (Bray \& Curtis 1957). MDS was performed on the resulting matrix to provide a 2-dimensional solution. Differences among sites were further evaluated using the nonparametric randomisation procedure ANOSIM (Clarke \& Green 1988, Clark 1993). The procedure constructs a test statistic ( $R$ ) based on similarities of replicates within and between sites. This value is then tested for significance against a null distribution constructed from random sampling of all possible permutations of the sample labels (Clarke 1993).

\section{RESULTS}

\section{Coral species richness patterns}

We recorded a total of 69 scleractinian coral species (26 Acropora species, 4 Montipora species and 39 species from other taxa) in surveys of the 7 sites (Table 1). In this study, 35 coral species were collected which had not previously been recorded from the Solitary Islands region (19 Acropora species, 2 Montipora species and 14 others). When these results are combined with the 55 species recorded prior to this study by Veron (1993), a total of 90 coral species in 28 genera from 11 families have now been recorded from the Solitary Islands region (Table 1). Twenty-one (38\%) of the 55 species previously recorded from the Solitary Islands by Veron (1993) were not found during this study. The most speciose genus was Acropora, with 30 species, but these species are largely restricted to the 2 most northern islands (Table 1). 
Table 1. Coral species recorded at the Solitary Islands during this study, and by Veron (1993). P: species present

\begin{tabular}{|c|c|c|c|c|c|c|c|c|c|c|c|c|c|c|c|c|c|}
\hline $\begin{array}{l}\text { Family } \\
\text { Species }\end{array}$ & $\begin{array}{l}\text { Mutt. } \\
\text { Is }\end{array}$ & $\begin{array}{l}\text { Wool. } \\
\text { Reel }\end{array}$ & $\begin{array}{l}\text { Split } \\
\text { Sol. }\end{array}$ & $\begin{array}{l}\text { SW } \\
\text { Sol. }\end{array}$ & $\begin{array}{l}\text { South } \\
\text { Sol. }\end{array}$ & $\begin{array}{l}\text { NW } \\
\text { Sol. }\end{array}$ & $\begin{array}{l}\text { North } \\
\text { Sol. }\end{array}$ & $\begin{array}{l}\text { Veron } \\
\text { (1993) }\end{array}$ & $\begin{array}{l}\text { Family } \\
\text { Species }\end{array}$ & $\begin{array}{l}\text { Mutt. } \\
\text { Is. }\end{array}$ & $\begin{array}{c}\text { Wool. } \\
\text { Reef }\end{array}$ & $\begin{array}{l}\text { Split } \\
\text { Sol. }\end{array}$ & $\begin{array}{l}\text { SW } \\
\text { Sol. }\end{array}$ & $\begin{array}{l}\text { South } \\
\text { Sol. }\end{array}$ & $\begin{array}{l}\text { NW } \\
\text { Sol. }\end{array}$ & $\begin{array}{l}\text { North } \\
\text { Sol. }\end{array}$ & $\begin{array}{l}\text { Veron } \\
\text { (1993) }\end{array}$ \\
\hline Pocilloporidae & & & & & & & & & Agariciidae & & & & & & & & \\
\hline Pocillopora damucornis & $\mathrm{P}$ & $\mathrm{P}$ & $\mathrm{P}$ & $\mathrm{P}$ & $\mathrm{P}$ & $\mathrm{p}$ & $\mathrm{P}$ & $\mathrm{P}$ & Pavona minuta & & & & & & & $\mathrm{P}$ & \\
\hline Stylophora pistullata & & & $\mathrm{P}$ & & $\mathrm{P}$ & $\mathrm{P}$ & $\mathrm{p}$ & $\mathrm{p}$ & P. varians & & & & & $\mathrm{p}$ & & & $\mathrm{p}$ \\
\hline Acroporidae & & & & & & & & & P. explanulata & & & & & & & $\mathrm{p}$ & $\mathrm{P}$ \\
\hline Acropora palmerae & & & & & & $\mathrm{p}$ & $\mathrm{p}$ & & P. venosa & & & & & & & $\mathrm{P}$ & $\mathrm{P}$ \\
\hline A. dánai & & & & & & & $\mathrm{p}$ & $\mathrm{P}$ & Leptoseris hawaiiensis & & & $\mathrm{P}$ & & & & & $\mathrm{p}$ \\
\hline A. formosa & & & & $\mathrm{p}$ & & & & & Fungiidae & & & & & & & & \\
\hline A. robusta & & & & & & $\mathrm{P}$ & $\mathrm{P}$ & & Cycloseris curvata & & & & & & & & $\mathrm{P}$ \\
\hline A. millepora & & & & & & $\begin{array}{l}p \\
p\end{array}$ & $\begin{array}{l}\mathrm{P} \\
\mathrm{p}\end{array}$ & $\mathrm{P}$ & Pectiniidae & & & & & & & & \\
\hline A. glauca & & & & $\mathrm{p}$ & & $\begin{array}{l}\mathrm{p} \\
\mathrm{p}\end{array}$ & $\begin{array}{l}p \\
p\end{array}$ & $p$ & Echinophyllia aspera & & & $\mathrm{P}$ & & & & & $\mathrm{p}$ \\
\hline A. clathrata & & & & & & $\mathrm{P}$ & $\mathrm{P}$ & & Mycedium elephantotus & & & $\mathrm{p}$ & & & & $\mathrm{p}$ & \\
\hline A polystoma & & & & & & $\frac{\mathrm{b}}{\mathrm{p}}$ & $\frac{b}{b}$ & & Mussidae & & & & & & & & \\
\hline A. cytherea & & & $\mathrm{p}$ & $P$ & & $\mathrm{p}$ & $\mathrm{P}$ & $\mathrm{P}$ & Acanthastrea hillae & & & & & & & & $p$ \\
\hline A. hyacinthus & & & & & & $\mathrm{p}$ & $\mathrm{p}$ & $\mathrm{P}$ & A. bowerbanki & & $\mathrm{P}$ & $\mathrm{P}$ & $\mathrm{P}$ & $\mathrm{P}$ & & & \\
\hline A. digutifera & & & & $\mathrm{P}$ & & & & & A echinata & & & & $\mathrm{P}$ & $\mathrm{P}$ & $\mathrm{P}$ & $\mathrm{P}$ & \\
\hline A. listern & & & & & & $\mathrm{P}$ & $\mathrm{p}$ & & A. Jordhowensis & $\mathrm{P}$ & $\mathrm{P}$ & $\mathrm{P}$ & $\mathrm{P}$ & $\mathrm{P}$ & $\mathrm{P}$ & & \\
\hline A dendrum & & & & & & $\mathrm{P}$ & $\mathrm{p}$ & & Blastomussa merleti & & & & & & & & $P$ \\
\hline A. solutaryensis & $p$ & $\mathrm{P}$ & $P$ & $\mathrm{P}$ & $\mathrm{P}$ & $\mathrm{P}$ & $\mathrm{P}$ & $\mathrm{P}$ & Scolymia australis & & & & & & & & $\mathrm{p}$ \\
\hline A. lutkeni & & & & & & & $\mathrm{P}$ & & Symphyllia radians & & & & & & & & $\mathrm{P}$ \\
\hline A. valida & & & $\mathrm{P}$ & $\mathrm{P}$ & $\mathrm{P}$ & $P$ & $\mathrm{P}$ & $p$ & Merulinidae & & & & & & & & \\
\hline A. nasuta & & & & $\mathrm{p}$ & & $\mathrm{P}$ & $\mathrm{P}$ & & Hydnophora exesá & & & & & & & $\mathrm{P}$ & $\mathrm{P}$ \\
\hline A. latistella & & & & & & & & $\mathrm{P}$ & H. microconus & & & & & & $\mathrm{p}$ & $\mathrm{p}$ & $\mathrm{P}$ \\
\hline A. pulchra & & & & & & & $\mathrm{p}$ & & H. pilosa & & & & & & $p$ & $p$ & $P$ \\
\hline $\begin{array}{l}\text { A. chesterfieldensis } \\
\text { A. cerealis }\end{array}$ & & & & & & & $\begin{array}{l}P \\
P\end{array}$ & & Faviidae & & & & & & & & \\
\hline $\begin{array}{l}\text { A. ceredils } \\
\text { A. florida }\end{array}$ & & & & $\mathrm{p}$ & & $\begin{array}{l}p \\
p\end{array}$ & $\begin{array}{l}\mathrm{P} \\
\mathrm{p}\end{array}$ & & Plesiastrea versipora & $P$ & $\mathrm{P}$ & $\mathrm{p}$ & & & & $P$ & $P$ \\
\hline A. loripes & & & & $r$ & & p & & & Cyphastrea serailea & & $\mathrm{p}$ & $\mathrm{P}$ & & $\mathrm{p}$ & $\mathrm{P}$ & & $\mathrm{P}$ \\
\hline A. sarmentosa & & & & & & $\begin{array}{r}\mathrm{P} \\
\mathrm{P}\end{array}$ & & & C. chalcidicum & & & & $\mathrm{p}$ & & & & \\
\hline A. anthocercis & & & & & $\mathrm{p}$ & & & & Goniastrea australensis & $\mathrm{P}$ & $\mathrm{P}$ & $\mathrm{P}$ & $\mathrm{p}$ & $\mathrm{P}$ & $\mathrm{p}$ & $\mathrm{P}$ & $\mathrm{p}$ \\
\hline A. granulosa & & & & & $P$ & $\mathrm{p}$ & & & G. favulus & & & & $\mathrm{P}$ & & & $\mathrm{P}$ & \\
\hline A. verweyi & & & & & & & & $p$ & G. pectinata & & & & & & & & $\mathrm{P}$ \\
\hline A. wilhsae & & & & & & & & $\frac{b}{b}$ & Platygyra daedalea & & & & & & & & p \\
\hline A. yongei & & & & & & & & 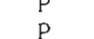 & P. lamellina & & & & & & & & $\mathrm{P}$ \\
\hline Montipora venosa & & & & & & $\mathrm{p}$ & $P$ & & Leptastrea transversa & & & & & & & $\mathrm{p}$ & \\
\hline M. spongodes & & & & & & & p & $p$ & Montastrea curta & & & $\mathrm{P}$ & $\mathrm{p}$ & $P$ & $\mathrm{P}$ & $\mathrm{P}$ & $\mathrm{P}$ \\
\hline M. turtlensis & & & & & & & p & $P$ & M. magnistellata & & & $\mathrm{P}$ & & $\mathrm{P}$ & & $\mathrm{p}$ & \\
\hline M. efflorescens & & & & & & & $p$ & & M. cf. valenciennesi & & & & & & & $\mathrm{p}$ & \\
\hline$M$ angulata & & & $\mathrm{P}$ & & & $\mathrm{P}$ & $\mathrm{P}$ & $p_{p}$ & Favites halicora & & & & & & & & $\mathrm{P}$ \\
\hline M.danae & & & & & & & & p & F flexuosa & $\mathrm{p}$ & & & & & & & $\mathrm{p}$ \\
\hline M. mollhs & & & & & & & & $\mathrm{p}$ & F. abdita & $\mathrm{P}$ & $\mathrm{P}$ & & & & & $\mathrm{p}$ & $\mathrm{p}$ \\
\hline Poritidae & & & & & & & & & F. russelh & & & & & & & & $P$ \\
\hline Porites heronensis & & & $\mathrm{p}$ & $\mathrm{p}$ & $\mathrm{P}$ & $\mathrm{P}$ & $\mathrm{p}$ & $\mathrm{p}$ & $\begin{array}{l}\text { Favia slelligera } \\
\text { F. favus }\end{array}$ & & & & & & & & $\frac{5}{b}$ \\
\hline Gomopora lobata & & & $\mathrm{P}$ & & & $p$ & & $P$ & Dendrophylliidae & & & & & & & & \\
\hline $\begin{array}{l}\text { G. djlboutiensis } \\
\text { G. stokesi }\end{array}$ & & & & & & $\mathrm{p}$ & $p$ & $P$ & Turbinaria radicalis & $\mathrm{p}$ & $\mathrm{p}$ & $\mathrm{p}$ & $\mathrm{p}$ & $\mathrm{p}$ & $\mathrm{P}$ & $\mathrm{p}$ & $\mathrm{p}$ \\
\hline G. norfolkensis & & & & & $p$ & & $P$ & & T. mesenterina & $\mathrm{P}$ & $\mathrm{P}$ & & $\mathrm{p}$ & $\mathrm{p}$ & $\mathrm{P}$ & & $\mathrm{P}$ \\
\hline Siderastreidae & & & & & & & & & $T$. frondens & $\mathrm{P}$ & $\mathrm{P}$ & $\mathrm{P}$ & $\mathrm{P}$ & $\mathrm{P}$ & $\mathrm{p}$ & $\mathrm{p}$ & $\mathrm{p}$ \\
\hline $\begin{array}{l}\text { Siderastreidae } \\
\text { Psammocora haimeana }\end{array}$ & & & $p$ & & & & & $\mathrm{D}$ & T. patula & & & & & & & $\mathrm{P}$ & $\mathrm{P}$ \\
\hline P. superficialss & $p$ & $P$ & $\begin{array}{l}\mathrm{p} \\
\mathrm{p}\end{array}$ & $P$ & $P$ & $\mathrm{p}$ & $p$ & $\frac{p}{p}$ & r. peltala & $\mathrm{P}$ & & & & & $\mathrm{P}$ & $\mathrm{P}$ & $\mathrm{P}$ \\
\hline Coscinaraea mcneilli & $\mathrm{P}$ & $\mathrm{p}$ & $p$ & & & & p & & Heteropsammia cochlea & & & & & & & & $\mathrm{P}$ \\
\hline$C$ columna & & & & & & & & $\mathrm{p}$ & Species total: 90 & 13 & 14 & 23 & 21 & 19 & 38 & 49 & 55 \\
\hline
\end{tabular}


Table 2. Summary of cover of dominant benthic organisms and substratum types in the Solitary Islands group as a mean of four $20 \mathrm{~m}$ line transects, and summary of coral species diversity for specimens collected during these surveys

\begin{tabular}{|c|c|c|c|c|c|c|c|}
\hline & $\begin{array}{l}\text { Muttonbird } \\
\text { Island }\end{array}$ & $\begin{array}{l}\text { Woolgoolga } \\
\text { Reef }\end{array}$ & $\begin{array}{l}\text { Split } \\
\text { Solitary }\end{array}$ & $\begin{array}{l}\text { SW } \\
\text { Solitary }\end{array}$ & $\begin{array}{l}\text { South } \\
\text { Solitary }\end{array}$ & $\begin{array}{c}\text { NW } \\
\text { Solitary }\end{array}$ & $\begin{array}{l}\text { North } \\
\text { Solitary }\end{array}$ \\
\hline Hard coral & 8.5 & 14.5 & 34.5 & 50.9 & 14.6 & 26.2 & 32.4 \\
\hline Soft coral & 2.4 & 10.2 & 7.1 & 1.6 & 0.3 & 7.2 & 0.9 \\
\hline Invertebrates $^{\mathrm{d}}$ & 1.6 & 3.4 & 5.2 & 5.6 & 7.9 & 9.3 & 2.5 \\
\hline Macroalgae dominated ${ }^{b}$ & 55.5 & 70.4 & 0 & 0 & 0 & 0.9 & 0 \\
\hline Mixed algae and invertebrates ${ }^{r}$ & 17.8 & 0 & 44.0 & 4.1 & 44.3 & 27.1 & 5.2 \\
\hline Dead coral & 0 & 0 & 0.8 & 0.4 & 1.6 & 4.7 & 5.9 \\
\hline Rock & 0 & 0 & 0.4 & 29.4 & 17.9 & 13.4 & 52.0 \\
\hline Sand and rock & 11.7 & 1.6 & 8.2 & 6.2 & 13.2 & 7.0 & 1.5 \\
\hline $\begin{array}{l}\text { No. coral species } \\
\text { in line transects }\end{array}$ & 6 & 7 & 10 & 11 & 11 & 13 & 15 \\
\hline \multicolumn{8}{|l|}{ Coral species in initial surveys: } \\
\hline Total & 11 & 11 & 13 & 19 & 17 & 31 & 43 \\
\hline Acroporidae & 1 & 1 & 2 & 6 & 2 & 13 & 18 \\
\hline Non-Acroporidae & 10 & 10 & 11 & 13 & 15 & 18 & 25 \\
\hline \multicolumn{8}{|c|}{$\begin{array}{l}\text { 'Invertebrates, such as barnacles, solitary ascidians, zooanthids, echinoids and sponges, not generally found in a mixed } \\
\text { algal community } \\
{ }^{b} \text { Either entirely kelp dominated, or mixed closely with a mixed invertebrate community }\end{array}$} \\
\hline
\end{tabular}

Coral species richness in the surveys ranged from 13 species at Muttonbird Island and at Woolgoolga Reef to 49 species at North Solitary Island (Tables $1 \& 2$ ). Fourteen $(28 \%)$ of the 49 coral species recorded from North Solitary Island were found only at that site (Table 1). NW Solitary Island had the second-highest coral species richness, with 38 species. Split Solitary, SW Solitary and South Solitary Islands had an intermediate number of coral species present $(23,21$ and 19 species respectively). Similar trends in species richness are evident from the numbers of coral species recorded in line transects at the 7 survey sites (Table 2). The Family Acroporidae shows the most significant variation in species richness between sites, ranging from 1 species at the onshore sites ( $<8 \%$ of coral species) to 21 species at NW Solitary and 24 species at North Solitary Islands (55 and $49 \%$ of coral species, respectively). Species from the other scleractinian families range from a minimum of 12 species at Muttonbird Island and at Woolgoolga Reef to a maximum of 25 species at North Solitary Island (Table 2).

\section{Benthic community structure}

The results of the line transect surveys show clear differences between the inshore sites, which are dominated by macroalgae and have relatively low hard coral cover $(<15 \%)$, and the 5 island sites which generally have much higher coral cover and species rich- ness, and lower algal cover (Table 2). Coral cover was highest at SW Solitary Island, with a mean of $50.9 \%$ cover in the area surveyed, and with cover approaching $100 \%$ in patches. South Solitary has the lowest coral cover of the offshore islands, with a similar coral cover $(14.6 \%)$ to the inshore sites (Table 2). A summary of the dominant coral taxa at each site is given in Table 3. Turbinaria species tend to dominate onshore reefs, Acropora species dominate North Solitary Island, while the other islands are dominated by a range of Acropora, faviid and Turbinaria species, Pocillopora damicornis and Porites heronensis.

The results of the nonmetric MDS are shown in Fig. 3. Replicates from most sites group together, but there is some overlap between samples from NW. Split and SW Solitary Islands in the central part of the plot. Samples are grouped within the plot in an approximate gradient of distance offshore, along the principal $(x)$ axis. Thus samples from the nearshore sites (WR and MI) and the site furthest offshore (N) group to the left and right respectively (Fig. 3).

Tests for differences among the sampling sites using ANOSIM (Clarke \& Green 1988, Clarke 1993) indicated that with the exception of South Solitary Island versus NW Solitary Island $(p=0.086)$ all pairs of sites were significantly different from each other.

In order to determine which species/habitat types were primarily responsible for differences among the sites, SIMPER (similarity percentage) breakdowns were performed (Clarke 1993). This procedure deter- 
Table 3. Summary of the scleractinian coral cover of the dominant species ( $>1 \%$ cover) from line transects at each site. Results show mean (SD) of percentage cover in four $20 \mathrm{~m}$ line transects

\begin{tabular}{|c|c|c|c|c|c|c|c|}
\hline & $\begin{array}{l}\text { Muttonbird } \\
\text { Island }\end{array}$ & $\begin{array}{c}\text { Woolgoolga } \\
\text { Reef }\end{array}$ & $\begin{array}{c}\text { Split } \\
\text { Solitary }\end{array}$ & $\begin{array}{c}\text { SW } \\
\text { Solitary }\end{array}$ & $\begin{array}{l}\text { South } \\
\text { Solitary }\end{array}$ & $\begin{array}{c}\text { NW } \\
\text { Solitary }\end{array}$ & $\begin{array}{l}\text { North } \\
\text { Solitary }\end{array}$ \\
\hline Pocillopora damicornis & $1.2(2.4)$ & $1.9(0.69)$ & $2.7(1.23)$ & $5.3(1.18)$ & $3.4(1.50)$ & $4.1(3.22)$ & $9.8(4.88)$ \\
\hline Porites heronensis & & & & $5.8(4.06)$ & $1.0(0.57)$ & $2.0(1.90)$ & $1.0(0.93)$ \\
\hline Acropora solitaryensis & & & $6.6(4.23)$ & $9.6(7.21)$ & $2.6(2.73)$ & $7.7(2.92)$ & \\
\hline A. nasuta & & & & & & & $4.2(3.98)$ \\
\hline A. hyacinthus & & & & & & $1.2(2.40)$ & \\
\hline A. robusta & & & & & & & $8.2(4.57)$ \\
\hline A. cerealis & & & & & & & $2.1(2.67)$ \\
\hline Turbinaria frondens & & & $15.5(6.17)$ & $13.3(4.49)$ & & $7.7(2.92)$ & \\
\hline T. mesenterina & $3.1(2.5)$ & $5.9(2.74)$ & $1.1(2.27)$ & & & & \\
\hline T. radicalis & $2.3(2.4)$ & & & $2.6(3.07)$ & $2.1(2.51)$ & & \\
\hline Goniastrea australensis & $1.2(1.0)$ & $1.5(3.00)$ & $6.1(3.31)$ & $9.3(5.16)$ & $1.3(2.60)$ & $4.9(1.42)$ & \\
\hline Cyphastrea serailea & & $1.5(3.00)$ & & $1.9(2.23)$ & $1.9(2.59)$ & & \\
\hline Psammacora superficialis & & $1.2(1.70)$ & & & & & \\
\hline
\end{tabular}

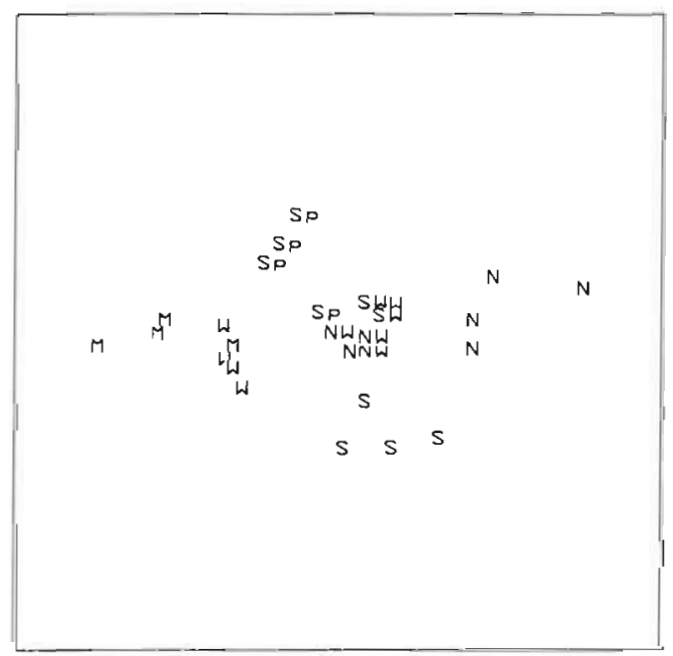

Fig. 3. MDS plot for data from benthic line transects at 7 sites within the Solitary Islands (Kruskal's stress $=0.136)$. $M=$ Muttonbird Island, $\mathrm{W}=$ Woolgoolga Reef, $\mathrm{Sp}=$ Split Solitary Island, $\mathrm{SW}=$ South West Solitary Island, $\mathrm{S}=$ South Solitary Is]and, $\mathrm{NW}=$ North West Solitary Island, $\mathrm{N}=$ North Solitary Island

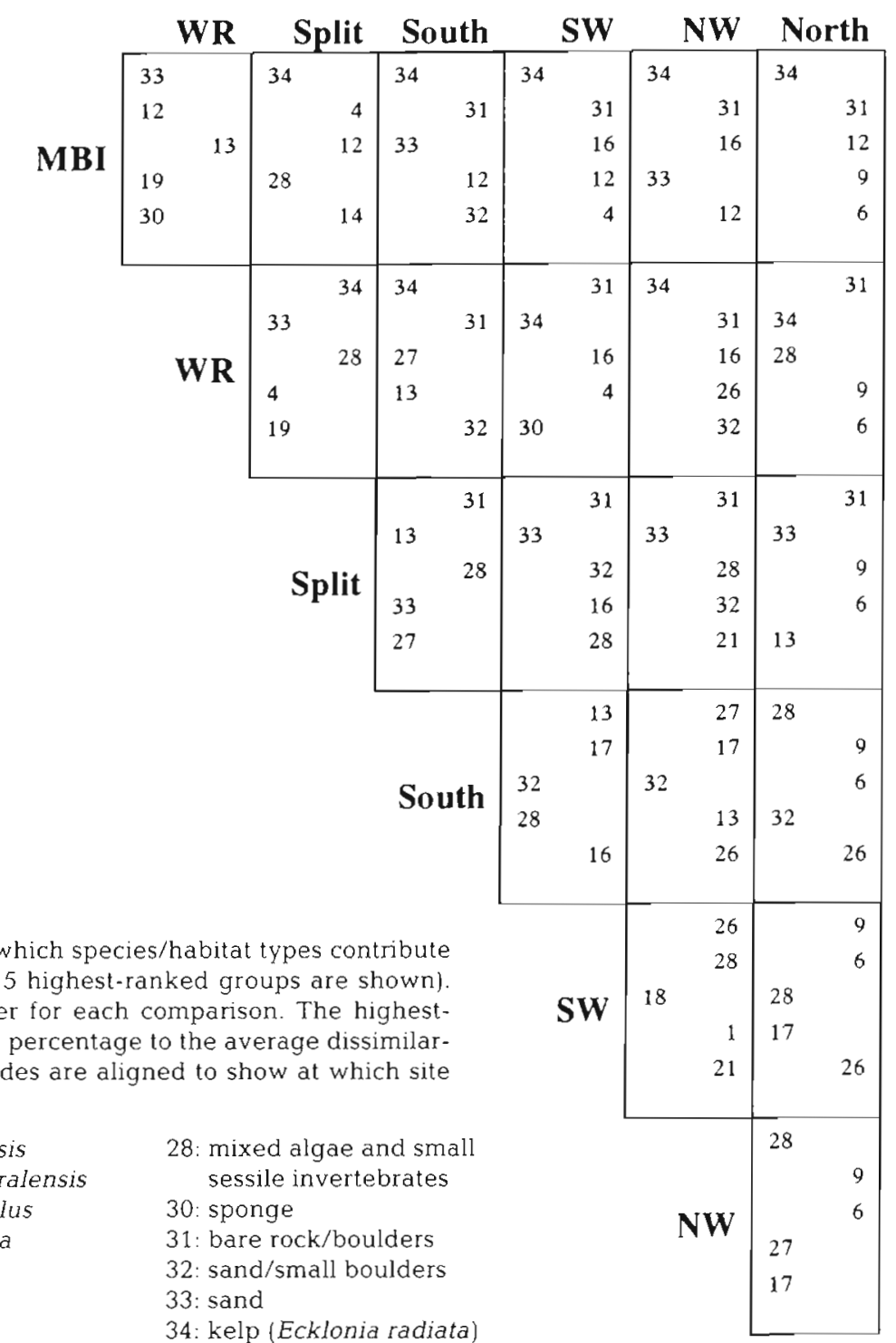

Fig. 4. Results of SIMPER breakdowns to determine which species/habitat types contribute most to the average dissimilarity between sites (the 5 highest-ranked groups are shown). Species/habitats (coded) are presented in rank order for each comparison. The highestranked group (i.e. contributing the highest individual percentage to the average dissimilarity) appears first within each cell. Species/habitat codes are aligned to show at which site they had the higher cover.

\author{
1. Acanthastrea lordhowensis \\ 4: Acropora solitaryensis \\ 6: A. nasuta \\ 9: A. robusta \\ 12: Pocillopora damicornis \\ 13/14: Turbinaria (mesenterina \\ and frondens) \\ 16: Porites heronensis \\ 17: Goniastrea australensis \\ 18: Goniastrea favulus \\ 19: Montastrea curta \\ 26: dead coral \\ 27: soft coral
}

34: kelp (Ecklonia radiata) mixed algae and small

32: sand/small boulder 
richness, and a greater area of bare rock surface. Several hypotheses can be proposed to account for the differences between South Solitary and the other island sites. South Solitary Island lies more than $20 \mathrm{~km}$ to the south of the other 2 most offshore sites (North and NW Solitary Islands), and it is possible that the currents in the region may not be conducive to moving or returning coral larvae to this island. Alternatively, because the island is surrounded by only a small area of shallow rocky platform, compared with the more extensive shallow bays on the other islands, it may therefore support fewer coral species. Thirdly, the coral communities at South Solitary Island appear to have been subjected to strong wave action. The relatively unprotected nature of the shoreline may mean that coral colonies are damaged or removed by adverse hydrodynamic conditions more frequently at South Solitary Island compared with the other island sites.

Veron et al. (1974) concluded from their general surveys that coral communities on all the islands were similar with the exception of North Solitary Island. The quantitative data reported here largely support these conclusions, but also discriminate NW Solitary Island on the basis of a higher coral species richness and higher acroporid abundance, and South Solitary Island because of its low coral cover and only moderate species richness relative to the other more offshore islands.

Bare rock was a major component of the substratum at most of the island sites, while dead coral surfaces were generally not abundant. This reflects the fact that these communities, while having significant cover of coral, are not forming limestone reefs, and instead form a veneer of coral growing on rocky substrata. A small increase in the presence of dead coral surfaces was found for the most offshore reefs, and may indicate that these reefs lie along a spectrum with respect to reef formation. For some reason, the apparently healthy, high cover coral communities at the Solitary Islands fail to accrete at a rate which compensates for loss of the coral substratum over geological time scales. The reasons for this failure are presently unclear, but may include very slow growth rates of the corals (Johannes et al. 1983), periodic high mortality through sudden changes in minimum water temperature (Veron \& Done 1979), failure of coral reproduction or recruitment (Yonge 1940, Wells 1957), or removal of the corals from the reef surfaces through periodic severe storms.

In the subtropical reefs of Western Australia, competition with macroalgae has been hypothesised as the most significant factor limiting coral reef formation (Johannes et al. 1983). At the Solitary Islands, fleshy macroalgae were relatively uncommon on the offshore islands and there was no evidence that competition with macroalgae inhibits coral growth, although it is possible that competition with algae may operate at the recruitment stage. Long-term studies of these coral communities are required to test these hypotheses

\section{Coral biogeographic patterns}

One of the most interesting aspects of the coral communities at the Solitary Islands concerns their diverse biogeographic origins. Unilike coral communities from the Great Barrier Reef region, which are totally dominated by tropical scleractinian species, the coral communities at the Solitary Islands contain a unique association of tropical species, some subtropical species, and a temperate water species. Of the 90 scleractinian species recorded from the Solitary Islands to date, 77 $(85 \%)$ are essentially tropical species found throughout the Great Barrier Reef region, and which are at, or near, their southern distribution limit at the Solitary Islands (Table 1; Veron 1986, 1993). A further 11 species $(12 \%)$ are generally rare or absent from tropical reefs, and are more common on subtropical and highlatitude reefs. The primarily subtropical suite of species comprises: Acropora glauca and A. solitaryensis, Pontes heronensis, Acanthastrea bowerbanki, A. hillae and A. lordhowensis, Scolymia australis, Hydnophora pilosa, Goniastrea australensis, Turbinaria patula and T. radicalis. In contrast, Plesiastrea versipora is found throughout tropical and high-latitude reefs around Australia, while Coscinaraea mcneilli is a temperate water species restricted to southern Australia (Veron 1993).

Thus, the unexpectedly high number of coral species present at the Solitary Islands is partly attributable to the biogeographic overlap of different coral faunas. A similar biogeographic mixing of tropical, subtropical and temperate marine species has been reported in surveys of the fish fauna (Pollard 1982) and algae (Chidgey 1987, Millar 1990) in the Solitary Islands region. Together these data indicate that the Solitary Islands marine communities are important not only for their species diversity, but also for their unique biogeographic composition. Although the subtropical species account for only $12 \%$ of the total number of coral species recorded, many of them are locally abundant and make major contributions to coral cover. Among the subtropical species, Acropora solitaryensis, A. glauca, Porites heronensis, Goniastrea australensis and Turbinaria radicalis were dominant in line transects at some of the survey sites (Table 3 ).

Ten of the 35 species recorded for the first time in this study have not previously been recorded south of the Great Barrier Reef region along the east coast of Australia (Veron 1993). These include: Acropora poly- 
stoma, A. chesterfieldensis, A. formosa, A. dendrum, $A$. cerealis, A. loripes, A. granulosa, Goniopora stokesi, $G$. norfolkensis and Cyphastrea chalcidicum. However, some of these species have recently been recorded in unpublished surveys of subtropical reefs at Moreton Bay, Brisbane (P. Harrison \& N. Holmes unpubl.), and at Lord Howe Island (V. Harriott, P. Harrison \& S. Banks unpubl.; Fig. 1). Most of the other species recorded for the first time at the Solitary Islands have previously been recorded at other subtropical reef sites along the east coast (Veron 1993). However, Hydnophora pilosa has not previously been recorded at a nearshore location along the east coast of Australia, and has only previously been recorded from the Elizabeth and Middleton reefs (Veron 1993; Fig. 1), and recently at Lord Howe Island (V. Harriott, P. Harrison \& S. Banks unpubl.). In contrast, the most northern record for Coscinaraea mcneilli was previously the south coast of NSW (Veron 1993), hence the Solitary Islands represent a new northern distribution record for this species along the east coast.

\section{Community changes over time}

There are no obvious changes to the general condition and structure of the coral communities at SW Solitary Island approximately $20 \mathrm{yr}$ after the surveys by Veron et al. (1974). The coral communities are dominated by the same species (taking into consideration likely name changes), and, where the quantitative surveys were done, areas of close to $100 \%$ coral cover are still present, as described by Veron et al. (1974). If major changes have occurred in the intervening period, then the communities have since recovered to be similar to those present in the earlier survey.

Patterns of coral community structure at the other island sites also appear to be similar to those described from qualitative surveys by Veron et al. (1974). However, the species composition appears to have changed over the intervening period. Twenty-one $(38 \%)$ of the 55 species recorded previously by Veron (1993) were not found during this study. It is possible that some of these species may still be present at the Solitary Islands, but were not observed during this study. The fact that 35 previously unrecorded coral species $(50 \%$ of the 69 species) were found in the coral surveys reported here, probably reflects at least some real changes in the coral community structure at these sites since the time of the original surveys. It is likely that future surveys over a greater area of reef will further increase the number of coral species recorded at the Solitary Islands.

With the exception of Acanthastrea lordhowensis, most of the new species recorded were relatively rare at the study sites, and most were found at North Solitary Island. These corals may represent new arrivals since the time of the previous surveys. The results indicate that a dynamic temporal pattern of species recruitment, survival and subsequent local extinction is occurring within these subtropical coral communities. The dominant coral species appear to be relatively stable, whereas some of the rarer species seem to appear and then disappear over time. A similar increase in the number of relatively rare coral species has also been found in recent surveys of other subtropical coral communities at Moreton Bay, Brisbane (Lovell 1989, P. Harrison \& N. Holmes unpubl.), and at Lord Howe Island off the NSW coast (Veron \& Done 1979, DeVantier \& Deacon 1990, V. Harriott, P. Harrison \& S. Banks unpubl.).

It is possible that some coral species can temporarily recruit to, and subsequently survive at, these southern sites, but fail to establish self-maintaining populations because of the very small number of colonies in the population, and the likelihood of larval dispersal away from these small isolated reefs (reviewed by Harrison $\&$ Wallace 1990). The population of the species may then disappear from the community until new recruits arrive from northern tropical or subtropical reefs via larval dispersal in the East Australia current. The consequence of this may be that over a very long time span, a large proportion of the tropical species pool might be recorded from these southern reefs, but only a subset will be present at any one time. If so, the total list of recorded species would increase slowly over time, while species richness in surveys might be expected to remain relatively static.

Acknowledgements. We thank Simon Banks and Mark Asquith for diving assistance, Chris Connell and Keith Cornish for assistance with boating, and Carden Wallace and Jacqueline Wolstenholme for assistance with identification of Acropora species. The analyses for this paper were carried out using the PRIMER programs developed at the Plymouth Marine Laboratory, UK. We thank Drs K. R. Clarke and R. M. Warwick for making both the software and documentation available. This project was support by a UNE-NR Internal Research Grant to V.H. and P.H.

\section{LITERATURE CITED}

A.I.M.S. (1987). An assessment of the distribution and effects of Acanthaster planci ( $L$ ) on the Great Barrier Reef, Parts 3, 4, 6, 7, 9. Australian Institute of Marine Science, Townsville

Bray, J. R., Curtis, J. T. (1957). An ordination of the upland forest communities of southern Wisconsin. Ecol. Monogr. 27 : $325-349$

Bull, G. D. (1982). Scleractinian coral communities of two inshore high island fringing reefs at Magnetic Island, North Queensland. Mar. Ecol. Prog. Ser. 7: 267-272

Chidgey, S. S. (1987). The marine macroflora of the Solitary 
Islands, New South Wales: Chlorophyta and Phaeophyta. M.Sc. thesis, University of Melbourne

Clarke, K. R. (1993). Non-parametric multivariate analysis of changes in community structure. Aust. J. Ecol. 18 : $117-143$

Clarke, K. R., Green, R. H. (1988). Statistical design and analysis for a 'biological effects' study. Mar. Ecol. Prog. Ser. 46: $213-226$

Dakin, W. J. (1952). Australian seashores. Angus and Robertson, Sydney

DeVantier, L. M., Deacon, G. (1990). Distribution of Acanthaster planci at Lord Howe Island, the southernmost Indo-Pacific reef. Coral Reefs 9: 145-148

Done, T. J. (1982). Patterns in the distribution of coral communities across the central Great Barrier Reef. Coral Reefs 1: 95-107

Field, J. G., Clarke, K. R., Warwick, R. M. (1982). A practical strategy for analysing multispecies distribution patterns. Mar. Ecol. Prog. Ser. 8: 37-52

Harrison, P. L., Wallace, C. C. (1990). Reproduction, dispersal and recruitment of scleractinian corals. In: Dubinsky, $Z$. (ed.) Coral reef ecosystems. Elsevier, Amsterdam, p. 133-207

Johannes, R. E., Wiebe, W. J., Crossland, C. J., Rimmer, D. W., Smith, S. V. (1983). Latitudinal limits of coral reef growth. Mar. Ecol. Prog. Ser. 11. 105-111

Lovell, E. R. (1989). Coral assemblages of Moreton Bay, Queensland, Australia, before and after a major flood. Mem. Queensl. Mus. 27: 535-550

McGuinness, K. A. (1990). Physical variability, diversity gradients and the ecology of temperate and tropical reefs. Aust. J. Ecol. 15: 465-476

Millar, A. J. K. (1990). Marine red algae of the Coffs Harbour region, northern New South Wales. Aust. Syst. Bot. 3: $1-301$

Pichon, M., Morrissey, J. (1981). Benthic zonation and community structure of South Island reef, Lizard Island (Great Barrier Reef). Bull. mar. Sci. 32: 581-593

Pollard, D. A. (1982). Proposal for a Marine Reserve in the waters of the Solitary Islands, Coffs Harbour-Wooli area of N.S.W. Internal report, July 1981. N.S.W. Dept of Agriculture and Fisheries, Sydney

Rosen, B. R. (1988). Progress, problems and patterns in the biogeography of reef corals and other tropical marine organisms. Helgoländer Meeresunters. 42: 269-301

Smith. S. D. A. (1988). An update of the 'Proposal for a Marine Reserve in the waters of the Solitary Islands, Coffs Har-

This article was submitted to the editor
bour-Wooli area of NSW' (Pollard 1982) and results from surveys of major coastal headland rock-platforms in the proposed marine park area. N.S.W Dept of Agriculture and Fisheries, Sydney

Smith, S. D. A., Simpson, R. D.(1991). Nearshore corals of the Coffs Harbour region, mid north coast, New South Wales. Wetlands (Australia) 11: 1-9

Stoddart, D. (1969). Ecology and morphology of recent coral reefs. Biol. Rev. 44: 433-498

Veron, J. E. N. (1974). Southern geographic limits to the distribution of Great Barrier Reef corals. Proc. 2nd int. Coral Reef Symp. 2: 465-473

Veron, J. E. N. (1986). Corals of Australia and the Indo-Pacific. Angus and Robertson, Sydney

Veron, J. E. N. (1993). A biogeographic database of hermatypic corals. Aust. Inst. mar. Sci. Monogr. Ser. 10

Veron, J. E. N., Done, T. J. (1979). Corals and coral communities of Lord Howe Island. Aust. J. mar. Freshwat. Res. 30: 203-236

Veron, J. E. N., How, R. A., Done, T. J., Zell, L. D., Dodkin, M. J., O'Farrell, A. F. (1974). Corals of the Solitary Islands, Central New South Wales. Aust. J. mar. Freshwat. Res. 25 : 193-208

Veron, J. E. N., Pichon, M. (1976). Scleractinia of Eastern Australia 1. Families Thamnasteriidae, Astrocoeniidae, Pocilloporidae. Aust. Inst. mar. Sci. Monogr. Ser. 1

Veron, J. E. N., Pichon, M. (1980). Scleractinia of Eastern Australia III. Families Agariciidae, Siderastreidae, Fungiidae, Oculinidae, Merulinidae, Mussidae, Pectinidae, Caryophylliddae, Dendrophylliidae. Aust. Inst. mar. Sci. Monogr. Ser. 4

Veron, J. E. N., Pichon, M. (1982). Scleractinia of Eastern Australia IV. Family Poritidae. Aust. Inst. mar. Sci. Monogr. Ser. 5

Veron, J. E. N., Pichon, M., Wijsman-Best, M. (1977). Scleractinia of Eastern Australia II. Families Faviidae, Trachyphylliidae. Aust. Inst. mar. Sci. Monogr. Ser. 3

Veron, J. E. N., Wallace, C. C. (1984). Scleractinia of Eastern Australia V. Family Acroporidae. Aust. Inst. mar. Sci. Monogr. Ser. 6

Wells, J. W (1955). A survey of the distribution of reef coral genera in the Great Barrier Reef region. Rep. Gt Barrier Reef Comm. 6: 21-29

Wells, J. W. (1957). Coral reefs. Mem. Geol. Soc. Am. 67: 609-631

Yonge, C. M. (1940). The biology of reef-building corals. Sci. Rep. Gt Barrier Reef Exped. 1: 353-391

Manuscript first received: November 5, 1993

Revised version accepted: March 10, 1994 